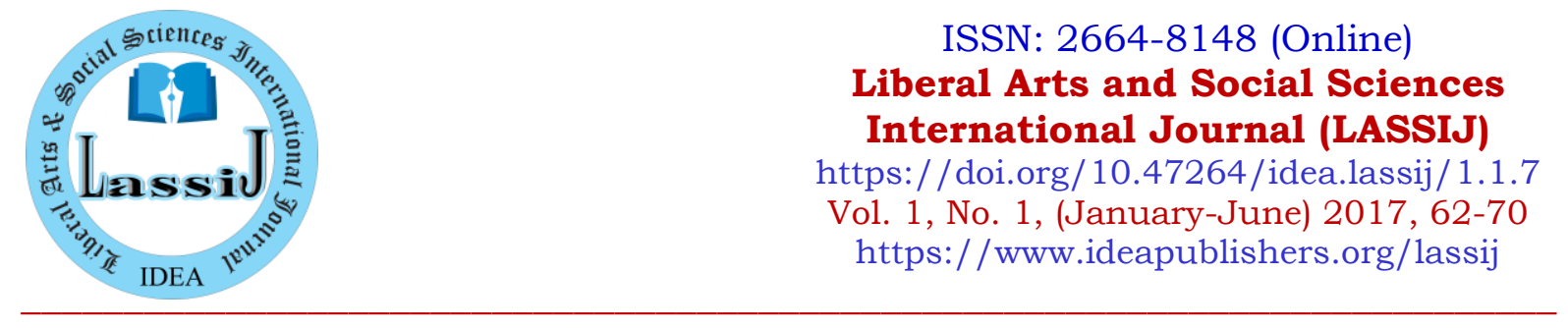

\title{
Impact of the Informal Institutional Forces on the Local Government Elections in Khyber Pakhtunkhwa, Pakistan
}

\author{
Niaz Ahmad ${ }^{1}$, Abida Bano ${ }^{2 *}$ and Ashfaq U. Rehman ${ }^{3-4}$ \\ 1. Department of Sociology, Faculty of Social Sciences, University of Peshawar, Pakistan \\ 2. Department of Political Science, Western Michigan University, Kalamazoo USA. \\ 3. Department of Political science, Faculty of Social Sciences, University of Peshawar, Pakistan \\ 4. Department of Research and Program Development, IDEA Peshawar, Peshawar Pakistan
}

\begin{abstract}
Local government is visualised as a tool for promoting political participation, downward accountability, which consequently leads to the establishment of good governance at the grass-root level. In the establishment of the local government system, the main ingredients of good governance, such as participation and downward accountability, reckon almost on the nature of elections. However, societies marked with strong cultural and socially embedded informal institutions, already existed from generations, hinder formal institutions to play its intended role. In Pakistan, some socio-cultural features like gender, ascribed status, and economic background of the individuals influence the entire process of elections adversely. This paper attempts to assess the processes of the local government elections in District Karak, Khyber Pakhtunkhwa Pakistan. It aims to highlight the deterministic role of other informal institutional forces that affect the outcome of local elections. It investigates, how the process of local government elections is influenced in Pakistan and how do people decide whom to vote for in these elections. The study argues that policymakers should work on strengthening the formal institutions of elections through measures such as monitoring by media, referendums, auditing, evaluations, education, and political awareness as alternatives to ensure good governance at the local level in Pakistan.
\end{abstract}

Keywords: Local Government, Election, Decentralisation, Accountability, Governance.

\section{Introduction}

Assessing role of the informal institutional forces is important since free and fair elections play a crucial role in ensuring downward accountability and establishing democratic local government. The role of local government and the elections (of formal institutions) is to establish an egalitarian system of governance at the local level to reduce the gaps between different tiers of government. However, institutional perspectives realize the impact of existing informal rules as well as informal institutions like power structure, gender, economic, and family status. In light of the literature, this paper describes in detail how the process of local government elections is influenced in Pakistan and how do people decide whom to vote for in the local government elections? The paper gives an assessment of the literature along with details about the methods adopted for this study. Thereafter, the collected data is analytically discussed in and key findings and suggestions are summarised in the concluding section. 


\section{Literature Review}

Realizing its promising outcomes in the field of governance, the World Bank considers decentralisation, as one of the critical reforms (Burki, Perry, \& Dillinger, 1999; World Bank, 2000). Decentralisation is considered instrumental in multiplying the chances of accountability and responsiveness of government and increasing citizens' voices in decision-making (Faguet, 2012). Accordingly, different countries in the world embarked upon introducing decentralised governance. In Bolivia, for example, the goals of decentralisation, as illustrated in Bolivian's Government Law (2010), were to enhance participatory decision-making, establish democracy at the grassroots, and improve socio-economic development. Similarly, Blair (2001) holds that the introduction of decentralisation in the United Kingdom was a move towards a more democratic, decentralised, and pluralistic state. In Peru, decentralisation's main aim was to pave the way for the active participation of the citizen in government (Government of Peru, 2011). Cambodia utilised decentralisation to shift democracy to the local level. The aim was to improve participation, democratic representation, and government effectiveness (Government of Cambodia, 2005; Romeo \& Spyckerelle, 2003). Likewise, Mexico embarked on decentralised governance to make the decision-making process more participatory (Munoz, Acosta, \& Moreno, 2006).

Public accountability is another determinant of governance, and, in the theory of a devolved local government, it is assumed that it enhances downward accountability of the elected local government's officials. Faguet (2011) argues that in a devolved local government system, local people elect their representatives, who actively respond to the preferences of their constituents for the ensure the longevity of their political careers. However, in a system where central or provincial governments appoints local officials instead of elections of local people, the direction of the accountability shifts upward. In such a system, local government officials take care of the preferences of the higher-level government instead of the local people (Riker, 1964). Smith (1985) elaborates on the advantages of decentralisation and argues that "there is correctness in this regard that a more significant level of accountability can be restored by local democracy. It can be said that local democracy has greater control than public corporations, appointed agencies, and field administration. The element of "elective" relates citizens with bureaucrats who make the entire procedure more meaningful as accountability is more visible in local government. Activities of political nature inside the local government, like elections, the pressure of political nature, rule-formulating, public debate and publicity, bridge the gap among citizens and their responsible administration along with the provision of opportunities for the handling of grievances" (p. 27).

Brinkerhoff (2001) discusses horizontal and vertical accountability. Horizontal accountability is a mechanism by which state actors or government officials at any level apply sanctions on each other. This type of accountability has no significance for the public in extracting services from government officials. However, its usefulness is undeniable in ensuring the accountability of the appointed officials to the elected officials. From ordinary people's perspective, vertical accountability is more important, mainly to get the attention of the elected representatives and to steer their actions towards public welfare. The mechanism of vertical accountability in the structure of the local government empowers local people to apply sanctions on the elected representatives if the decisions made are against the voices and choices of the local people. In this regard, Young (2000) holds that "citizens can only legitimately authorise representatives and hold them accountable if there are many avenues and institutions through which they engage with both, i.e., each other and their representatives" (p. 8). In this respect, Crook \& 
Sverrisson (2001) argue that holding free and fair elections is one of the crucial channels through which the public can hold their representatives accountable. Similarly, Ribot (2001) holds that local government elections are one of the avenues which help ensure accountability. However, the accountability of the elected representatives through elections is conditional to the essence and nature of electoral competitiveness. Open electoral competitiveness is vital in terms of enhancing the quality of governance (Agrawal \& Ribot, 1999). In this respect, Hallerberg (2004), in a study of Western European countries, found a link between high electoral competitiveness and low budget deficits.

Similarly, in another study of American States, Wibbels (2003) concludes that states with higher electoral competitiveness were less likely to seek a bailout package from the federal government. Furthermore, electoral competitiveness provides ample choices for the community members to elect trustworthy and honest representatives and reject the previously elected representatives if they had not come up to their expectations. Elections are generally considered as a mechanism of empowering people to elect their representatives and to get rid of the government officials that are not coming up to their expectations. The above definition considers elections as a vehicle that engages community members and their expected representatives mutually. The said engagement makes democratic local government instrumental in enhancing the accountability of the elected representatives downwards because their success depends on the support of local voters in the forthcoming elections. Therefore, they respond quickly to local people's voices to get the support of local voters (Faguet, 2011). Similarly, the Inter-Parliamentary Union (IPU) in its $154^{\text {th }}$ session held on 26 March 1994 in Paris declared criteria for Free and Fair Election to reassert that legitimacy of authority lies with the people (Goodwin-Gill 2006). This legitimacy makes the elected representatives accountable to their constituents.

As per rationalists, human nature being rational, make choices and decisions that serve their interests best. However, at the same time, they are placed in a complex social web wherein they interact with one another and with other collectivities (Granovetter, 1985). Therefore, based on embeddedness, normative institutionalists (see, for example, Peters, 1999) believe that it is misguiding to take individual an ultimate unit of analysis, because (s)he is influenced by their fellows and prevailing institutional forces other than rationally devised ones. In such situations, some institutional forces influence individuals more than others, for which he interprets the meaning of commitment (Peters, 1999). For example, elections provide an equal opportunity for male and female candidates to contest. However, in a patriarchal society like Pakistan, it is difficult for a female candidate to win elections against any male candidate due to obvious reasons of male presence and male acceptance in the public arena. A typical voter is reluctant to vote for any female candidate against a male candidate. (S)he is influenced more by the prevailing and socio-culturally embedded patriarchal practices than any newly introduced formal initiatives towards gender equality. Likewise, a candidate with weak economic background has little chance to win against a candidate with a strong economic background. In a nutshell, voters' choices are shaped by the persistent informal institutional forces; hence, play a vital role in the determination of elections result.

For rational choices institutionalists, institutions are more than only formal structures, and they argue that institutions are to be taken as a collection of rules, roles, and routines (March \& Olsen 1989). They further argue that institutions influence the behaviour of individuals for generations. The focus of their work is on the integrative version that they refer to as institutions providing proper ways of action. Institutions influence the behaviour of the members by an 
inherent normative system and provide various appropriate courses of action for different roles. Wherein, an individual actor chooses rationally from among the available courses. For example, for a locally elected leader in a local government system, and appropriate behaviour is to feel the pains of the local people and take possible remedial measures. In case of deviance, normative institutionalism also realises the importance of enforcement mechanism, and hence in the above-mentioned example, it may be in shape of a free and fair election and other accountability mechanisms to discourage the success of the representatives involved in antipublic welfare activities. However, it is mentioned above that an individual at the same time is influenced by several institutional forces where some institutions exert more pressure on him than others. In such situations, an individual is likely to be influenced by institutions exerting more pressure. Hence, we may argue that in the area where Pashtoon culture, characterised by strong patriarchy, is practiced, makes it extremely difficult for female candidates to win against the male candidate. Similarly, various sub-cultures, e.g., bribery, nepotism, and family pride, have been established and may shape the behaviour of local people and, consequently, threaten the implications of formal rules, regulations, and roles.

\section{Research Methodology}

This study adopts a qualitative approach to assess the voters' choices in the local government elections. Since the study aims at highlighting the role of informal rules in shaping voters' choices, thus a sample of 25 participants is selected through a purposive sampling technique from district Karak of Khyber Pakhtunkhwa. District Karak is selected for its unique features, such as low literacy rate, economic impoverishment, and culture practice. People make decisions for several reasons such as rationality, cultural pressure, family's influence, among others. Thus, this study asks the research question as "How do people decide whom to vote for in the local government elections?" To understand the factors responsible for voters "electing particular candidates, the researchers need to understand the meaning they attach to things and phenomena in their social settings (Hammersley, 2007). In the social sciences research, scholars are interested in the context where people attach meanings to different phenomena in diverse cultural settings (Hammersley, 1989). In so doing, the qualitative approach is engaged to evaluate the factors that influence the local governments 'elections. Qualitative method is considered an appropriate method to study social reality in detail (Ospina, 2004). The semistructured interview schedule is employed as the main data collection tool in the study. However, participant observation is used as an additional tool to understand the social environment fully and to note the non-verbal language and expressions of the respondents. All the participants are interviewed individually and are given one to two hours to express their views. Participation in the study was strictly voluntary, and the researcher took care of the privacy of the study participants by anonymizing the data.

\section{Discussion and Findings}

Defining accountability in terms of the governors and the governed, Lonsdale (1986) holds that "rulers claim to be responsible to their people; people try to hold them to account. Accountability is thus, the measure of responsibility" (p. 127). This definition is broader and general, in a sense. However, the definition presented by Brinkerhoff (2001) seems more relevant, who argues that "the essence of accountability is answerability; being accountable means having an obligation to answer questions regarding decisions and actions" (p. 2). This means that a decentralised local government ensures accountability because it refers to a system wherein locally elected representatives justify their actions and decisions made by them to their 
local public. This definition is more constituents-cantered and emphasizes the justification of the actions of the elected leaders.

However, the local government in Pakistan is observed inefficient to ensure any of the forms mentioned above of accountability. The majority of the respondents showed their dissatisfaction with the performance of their elected representatives. They stated that they introduced development projects through their agents while least bothered by actual feasibility and needs of the community. In developing a feasibility report of any development project, the choices of local people are ignored. Furthermore, community members are helpless to hold nazims (administrators) of union council, Tehsil administration, and District government accountable for their unpopular decisions, except to wait and take revenge from them by overthrowing them in the upcoming elections. Nazims often use false pretexts to avoid the demands of ordinary people. In this regard, Young (2000) holds that "citizens can only legitimately authorise representatives and hold them accountable if there are many avenues and institutions through which they engage with each other and also their representatives" (p. 8). Thus, the elections as a vehicle that mutually engages the community members and their expected representatives. The said engagement makes democratic local government instrumental in enhancing the accountability of the elected representatives downwards. This is because their success depends on the support of the local voters in the forthcoming elections. Therefore, they respond quickly to local people's voices to get the support of local voters (Faguet, 2011). However, in this study, nature of the situations is quite different. Moreover, vote of an individual is worthless.

In contrast to consulting the constituents and responding to their concerns, the elected representatives rely more on their traditional power bases as compared to the local voters 'aspirations. The irony is that local people depend on the elected representatives for their livelihoods in multiple ways. These elected local representatives not only command respect in the community but also hold the traditionally powerful positions in society, such as community elders. Henceforth, the elected representatives did not seem to need the political support of the community members per se. In other words, they could secure a vote without being responsive to the demands of the community. In contrast, community members needed the support of elected representatives now and then. Similarly, instead of relying on public votes, the incumbents prefer to use informal channels of influence such as kinship, social status as a means to win elections.

Furthermore, locally elected representatives use various kinds of unfair means to succeed in the elections. At times, they resort to tactics such as bribing the electoral officials, runing an expensive electoral campaign, vote-buying, pressurising the competitors, and also the local voters to win the local government elections. Although these malpractices are known to the community members; however, they, along with formal institutions like the Election Commission of Pakistan, seem to be ineffective in stopping it. As one of the community members in an individual interview said:

"We, Pakistanis, hope every time that the next elections would make a difference, but I think we are always wrong because the vote is not the only means to win elections. The power base and wealth of a candidate play a significant role in the whole game. We cast votes in favour of one candidate while experience declaration of success of another candidate the next morning." 
Moreover, the socio-economic background of the candidate has been observed as a striking determinant to decide the results of the election. In the prevailing political culture in Pakistan, candidates hire private vehicles for transportation of voters to the polling station to gain their support on the day of elections. The vehicles are handed over to different supporters in the constituency until the end of the election's day. The vehicle provision is a way of showing economic and social power that helps in creating a favourable and winning environment for the candidate. Another practice that is common in Pakistan is that candidates open their election offices in private buildings on the rental basis within the jurisdiction of their constituency and often near the polling station where local people are entertained with refreshment and food. Through these tactics, a candidate tries to impress the supporters, the neutral voters, and the competitors. These practices need a considerable amount of money and discriminate against the poor and middle-class candidates. Moreover, these factors are also observed, like the high expenses which the local election entails. The same has been verified by one of the community members who stated:

"For being a candidate, attributes of a personality do not matter, rather financial expenses determine the outcome of the election campaign. The entire process is a money game having no importance of character, and qualities required principally."

It has also been observed that besides economic status, the social status of a candidate has a significant role in determining the election results. There is a vivid influence of the existing caste system. It has been noticed that castes like Chumyar (shoemaker), Tharkanr (carpenter), Nai (hairdresser), and Kolal (mud pot makers) are being considered lower than the Zamindar (farmer/landowner). One of the respondents noted that (with the condition of not disclosing his identity), the moment you empower the people of these lower castes, their behaviour turns negative at once. Though the respondent has been a graduate, still he has been under the influence of cultural practices. It has been reported several times by the respondents that, apart from the role of money in electioneering, the social class of the candidates did matter. People from lower strata could not dare to contest in the elections because the majority of the constituents are unwilling to vote a person who belongs to any Kam Zat (lower caste). Caste and Biradri (kinship/clan) are observed as the decisive factors by the voters in shaping their choices about casting a vote.

Similarly, sex has also been observed as a deciding factor in contesting the elections. Women were socially deprived and are not allowed to run for the elections without the prior permission of the male family head. Therefore, a legacy of gender discrimination has been observed about women's representation. One of the respondents remarked:

"In our local area, the elders arranged a meeting before the elections and decided that women would not cast their votes and so banned them from taking an active part in the elections. It is a wise decision because it is a matter of honour for us that women should remain restricted to the boundaries of their homes."

Despite the government's reservation of 33\% seats in local government, women are still deprived of their due representation in local councils. Patriarchal practices are too strong to allow women to occupy their due spaces in the reconfigured system of local government. It is realised that the persisting gender-based discrimination has been deeply embedded in and is 
being reinforced through cultural practices. Its influence on most of the native male members has been due to the culturally embedded values; that is why they favoured the decision of barring women from taking part in the election. Although, the government's decision has been right to minimise gender centric discrimination by increasing women's representation; however, its implementation seems ineffective in overcoming the socio-cultural obstacles in their way. About the impact of the patriarchy on the women's political status, one of the participants shared:

\begin{abstract}
"When I heard about the decision of the elders of our area regarding the banning women to vote, I at once left my office, contacted some of the elders, and met them to address the problem as I felt it unfair to keep women deprived of their basic political right. Thanks' God, after continuous struggle for three days, I succeeded in persuading some of the elders, and then, in some of the areas (though not in the whole district), women could poll their votes."
\end{abstract}

Majority of the respondents stated that the government's machinery is responsible for the irregularities in conducting free and fair elections. In local government elections 2001 and 2005, the Session Judges and the Civil Judges were assigned the role of returning officers. According to most respondents, these returning officers were involved in the misuse of authority and deciding the election results according to their wishes. The respondents reported that in most of the cases, the financially well-off candidates bribed the respective returning officers and consequently got succeeded in the elections. Besides the returning officers, the presiding officers, the assistant presiding officers and the polling officers are also involved in the shady dealings with the influential candidates, thus affecting the process of elections.

The literature on elections emphasizes the importance of free and fair elections in ensuring accountability and good governance (Crook \& Sverrisson, 2001; Ribot, 2001) downwards. Nonetheless, in some cases, the elected representatives do not feel accountable to their respective constituents (Ribot, 2001) due to the prevailing elite culture and other contextual factors (Smoke, 2003; World Bank, 2000). Local elites secure positions of power through rigging elections in their favour, and hence, do not rely on the local voters. Community members are deprived of their fundamental political rights and are unable to hold their representatives accountable. In such a scenario, local elections become ineffective and do not yield the outcome of peoples' representation in the local democratic arrangements.

\title{
5. Conclusions
}

The importance of free and fair elections in establishing good local governance is undeniable. However, in countries like Pakistan, local as well as general elections usually are not free and fair but to a lesser degree. The questions that are raised to the legitimacy of the results of the election are rigging allegations, use of unfair means by the candidates to secure ministerial positions in the government set up, and so forth. These types of unfair means include bogus/fake votes, buying of votes, and bribing electoral officials, among others. Voter's choices in deciding the representatives seem mere formality and far from a deciding factor in the results of the elections. Besides the engagements, the elected representatives rely more on their traditional power base as compared to their voters, who often depend on them in different ways for their livelihood. Elected representatives do not need the political support of the local community, per se. 
In contrast, the community members need the support of the elected representatives. Similarly, instead of relying on public votes, the incumbents prefer to use unfair means in contesting the elections. Hence, it seems pertinent to strengthen other electoral processes like voting through the biometric system, independent monitoring, and implementation of election rules. Notwithstanding, the elections are the most common strategy of holding representatives downwardly accountable. Furthermore, the alternate means such as monitoring by media, referendums, auditing and evaluations, education, and political awareness could be used as alternative ways to enhance accountability downwards. Unfortunately, such measures did not exist or remained inactive to hold elected representatives accountable to their respective constituents in Pakistan. The available measures seemed ineffective against the local power structure. Therefore, the weakness of elections in introducing an egalitarian system of decisionmaking has been vivid. Besides the adverse effect of the local power structure on accountability, it also afflicts the community participation.

\section{References}

Agrawal, A., and Ribot, J. (1999). Accountability in decentralization: A framework with South Asian and West African environmental cases. The Journal of Developing Areas, 33(1), 473-502.

Blair, T. (2001, October 30). The Full Text of Blair's speech to the Welsh Assembly. Retrieved from: https://www.theguardian.com/world/2001/oct/30/september11.usa3

Bolivian's Government Law (2010). Autonomy and Decentralization Framework law. La Paz: Government of Bolivia.

Brinkerhoff, D. W. (2001). Taking account of accountability; A conceptual overview and strategic options: Draft report for the Implementing Policy Change Project, Phase 2. Washington, DC. Centre for Democracy and Governance, USAID. Abt. Associates, Inc., Mimeo.

Burki, S. J., Perry, G., and Dillinger, W. (1999). Beyond the centre: Decentralizing the state. Washington, DC: World Bank.

Charmaz, K. (2006). Constructing grounded theory: A practical guide through qualitative analysis. London: Sage.

Crook, R. C., and Sverrisson, A. S. (2001). Decentralization and poverty--alleviation in developing countries: A comparative analysis or is West Bengal unique? IDS Working Paper 130. Brighton: Institute of Development Studies.

Faguet, J. P. (2011). Decentralization and governance. In, STICERD: Economic Organization and Public Policy Discussion Papers Series, from Suntory and Toyota International Centres for Economics and Related Disciplines, LSE. Available at: https://econpapers.repec.org/paper/cepstieop/027.htm

Faguet, J. P. (2012). Decentralization and popular democracy: Governance from Below in Bolivia. University of Michigan Press.

Goodwin-Gill, G. S. (2006). Free and fair elections. Inter-Parliamentary Union.

Government of Cambodia (2005). Strategic framework for decentralization and deconcentration reforms. Phnom Penh: Government of Cambodia.

Government of Peru (2011). Decentralisation and Good Governance: Criteria and Recommendations for Accountability through public hearings. Retrieved from: http://www.defensoria.gob.pe/modules/Downloads/informes/ccr/rendicion_cuentas. pdf

Granovetter, M. (1985). Economic action and social structure: The problem of embeddedness. 
American Journal of Sociology, 91(3), 481-510.

Hallerberg, M. (2004). Domestic budgets in a United Europe: Fiscal governance form the end of Bretton Woods to EMU. Ithaca: Cornell University Press.

Hammersley, M. (1989). The dilemma of the qualitative method: Herbert Blumer and the Chicago Tradition. London: Routledge.

Hammersley, M. (2007). Assessing validity in social research. In P. Alasuutari (Ed.), Handbook of social research. London: Sage.

Lonsdale, J. (1986). Political accountability in African history. In P. Chabal (Eds.), Political domination in Africa (pp. 126-187). Cambridge, UK: Cambridge University Press.

March, J. G., and Olsen, J. P. (1989). Rediscovering institutions. New York: Free Press.

Munoz, L., Acosta, A., \& Moreno, L. (2006). Aspectos básicos de la descentralización en México. Mexico City: Instituto Nacional para el Federalismo y el Desarrollo Municipal.

Ospina, S. (2004). Qualitative research. In G. R. Goethals, G. S. Sorenson, \& J. M. Burns (Eds.), Encyclopaedia of leadership 2004 (pp. 1279-1284). Thousand Oaks, CA.

Peters, B. G. (1999). Institutional theory in political science: The new institutionalism. London: Pinter.

Ribot, J. C. (2001). Integral local development: Accommodating multiple interests through entrustment and accountable representation. International Journal of Agricultural Resources, Governance, and Ecology, 1(3-4), 327-350.

Riker, W. (1964). Federalism: Origin, operation, significance. Boston: Little, Brown, and Company.

Ritchie, J., Lewis, J., and Elam, G. (2003). Designing and selecting samples. In J. Ritchie \& J. Lewis (Eds.), Qualitative research practice: A guide for social science students and researchers (pp. 77-109). London: Sage.

Romeo, L. G., and Spyckerelle, L. (2003). Decentralization reforms and commune-level services delivery in Cambodia. Philippines: Asian Development Bank, UNCDF.

Smith, B. C. (1985). Decentralization: The territorial dimension of the state. London: George Allen.

Smoke, P. (2003). Decentralisation in Africa: Goals, dimensions, myths, and challenges. Public Administration and Development: The International Journal of Management Research and Practice, 23(1), 7-16.

Wibbels, E. (2003). Bailouts, budget constraints and Leviathans comparative federalism and lessons from the early United States. Comparative Political Studies, 36(5), 475-508.

World Bank (2000). Entering the $21^{\text {st }}$ century: World development report 1999/2000. Oxford: Oxford University Press.

Young, I. M. (2000). Hybrid democracy: Iroquois federalism and the postcolonial project. In D. Ivison, P. Pattonand, and W. Sanders (eds), Political Theory and the Rights of Indigenous Peoples. Cambridge: Cambridge University Press, 237-58. 